\title{
Ultra-Structural Alterations in Botrytis cinerea-The Causal Agent of Gray Mold-Treated with Salt Solutions
}

\author{
Khamis Youssef ${ }^{1, *(1)}$, Sergio Ruffo Roberto ${ }^{2}\left(\mathbb{D}\right.$ and Admilton G. de Oliveira ${ }^{3,4}(\mathbb{C}$ \\ 1 Agricultural Research Center, Plant Pathology Research Institute, 12619 Giza, Egypt \\ 2 Agricultural Research Center, Londrina State University, 86057-970 Londrina, PR, Brazil; sroberto@uel.br \\ 3 Biological Sciences Center, Londrina State University, 86057-970 Londrina, PR, Brazil; admilton@uel.br \\ 4 Laboratory of Electron Microscopy and Microanalysis, Londrina State University, 86057-970 Londrina, PR, \\ Brazil \\ * Correspondence: youssefeladawy@yahoo.com; Tel.: +2235724893
}

Received: 8 August 2019; Accepted: 28 August 2019; Published: 8 October 2019

\begin{abstract}
Potassium bicarbonate (PB), calcium chelate (CCh), and sodium silicate (SSi) have been extensively used as antifungal generally recognized as safe (GRAS) compounds against plant pathogenic fungi. In this research, in in vitro tests, the radial growth, conidial germination, and germ tube elongation of Botrytis cinerea was completely inhibited at $0.3 \%$ of $\mathrm{PB}, \mathrm{SSi}$, and CCh. In in vivo tests, application of $\mathrm{PB}, \mathrm{SSi}$, and $\mathrm{CCh}$ completely inhibited the occurrence of gray mold incidence of inoculated 'Italia' grape berries at concentrations of $1.0,0.8$, and $0.8 \%$, respectively. In order to investigate the detailed mechanisms by which salts exhibited antifungal activity, we analyzed their influence on morphological changes by scanning electron microscopy (SEM) and transmission electron microscopy (TEM) and also on reactive species of oxygen (ROS), mitochondrial membrane potential (MMP), and adenosine triphosphate (ATP) content. Defects such as malformation and excessive septation were detected on salt-treated hyphae morphology observed by SEM. The internal structure of conidia treated or not with salt solutions was examined by TEM. In treated conidia, most of the conidia were affected and cellular vacuolization and cytoplasmic disorganization was observed. For ROS accumulation, a higher increase was observed in fluorescent conidia in presence of PB, SSi, and CCh by 75,68 , and 70\% as compared to control, respectively. MMP was significantly decreased after salt application indicating a loss of mitochondria function. Also, luminescence showed that B. cinerea-conidia treated with salts contained less ATP than the untreated conidia. The results obtained herein are a step towards a comprehensive understanding of the mode of action by which salts act as antifungal agents against $B$. cinerea.
\end{abstract}

Keywords: Botrytis cinerea; salts; ATP; ROS; mitochondrial membrane potential

\section{Introduction}

Worldwide grape production estimated to be about $74,276.583$ tonnes and harvested area nearly $6,931.353$ ha with a yield $107160 \mathrm{hg} \mathrm{ha}^{-1}$ [1]. Botrytis cinerea, the causal agent of gray mold disease, is the second most significant phytopathogenic fungus around the world [2] and can infect several fresh fruit and vegetables worldwide, including table grapes, leading to severe economic losses [3-5]. Synthetic fungicides are regularly an important approach to control this disease. However, fungicide resistance has been detected in B. cinerea exposed to fungicides applied in grape vineyards [6]. In addition, market and regulatory pressure regarding residues and concerns of environmental and human health are increasing. In this context, new management techniques are needed to be adopted. Various studies have documented the strong antimicrobial activity of generally recognized as safe (GRAS) compounds 
including salts against postharvest diseases of several commodities counting table grapes [3,4,7-9]. Also, our previous results concluded that potassium bicarbonate (PB), calcium chelate (CCh), and sodium silicate (SSi) were the most effective salts against gray mold of 'Italia' and 'Benitaka' table grapes under artificial and natural field infections [3,4]. The benefits of salts, as alternative control means, are their incredible accessibility, simplicity of managing and use, and low cost when contrasted with different GRAS compounds [10].

From a quality point of view, preharvest treatment of $\mathrm{PB}$ and $\mathrm{CCh}$ was significantly effective in reducing mass loss and did not harm the film-forming properties of the 'Italia' berry skin, and it seems that they did not change cosmetic properties either [3]. In 'Benitaka' table grape, SSi did not influence the mass reduction, soluble solids content, and color index as compared to the water control [4]. Unfortunately, the information about the mechanism of action of those promising salts is poor. The mechanism of action still remains fundamentally unexplored. Understanding the mechanism of action of alternative control means such as salts may help to optimize their use against plant pathogens, particularly those attacking fruit and vegetables. It is outstanding that mitochondria are the fundamental source of cellular adenosine triphosphate (ATP) and play a focal role in an assortment of cell forms [11]. Also, mitochondria are the major endogenous source of reactive oxygen species (ROS), whose accumulation can prompt oxidation of macromolecules, resulting in mtDNA mutations, maturing, and cell apoptosis [12,13]. In any case, little data is available about whether PB, CCh, and SSi can cause mitochondrial damage of Botrytis conidia.

In the present research, effect of $\mathrm{PB}, \mathrm{CCh}$, and SSi on berry infection, pathogen radial growth, conidial germination, and germ tube elongation was explored. In addition, several approaches were carried out to investigate the mechanism of action of those salts including scanning electron microscopy (SEM), transmission electron microscopy (TEM), reactive species of oxygen (ROS) generation, conidium mitochondrial membrane potential (MMP), and adenosine triphosphate (ATP) content.

\section{Materials and Methods}

\subsection{Chemicals, Fungal Isolate, and Plant Materials}

Potassium bicarbonate (PB, $\mathrm{KHCO}_{3}$ 99.7-100.5\%) was purchased from Synth, SP, Brazil; calcium chelate ( $\mathrm{CCh}, \mathrm{C}_{10} \mathrm{H}_{12} \mathrm{~N}_{2} \mathrm{O}_{8} \mathrm{CaNa}_{2} \cdot 2 \mathrm{H}_{2} \mathrm{O} 98 \%$ ) was provided from Vetec Quimica Fina, Brazil and sodium silicate ( $\mathrm{SSi}, \mathrm{Na}_{2} \mathrm{O} 18 \%+\mathrm{SiO}_{2} 63 \%$ ) was supplied by Dinamica, $\mathrm{SP}$, Brazil. B. cinerea isolate (BC-UEL-1) used in this study was provided from the fungal collection in Londrina State University, Brazil [3]. The used strain was isolated from infected 'Italia' table grapes showing typical gray mold symptoms. Healthy table grapes (Vitis vinifera L. cv. Italia) were harvested at full ripe from a commercial vineyard located at Paraná (South Brazil), pooled together, sterilized in sodium hypochlorite solution $(1 \%)$ and were used for in vivo experiments.

\subsection{Effect of Salts on Gray Mold Disease}

The effect of $\mathrm{PB}, \mathrm{SSi}$, and $\mathrm{CCh}$ on controlling postharvest gray mold in vivo was evaluated as described in He et al. [5] with some optimization. In particular, 'Italia' grape berries were selected for uniformity, washed, sterilized, and air dried at room temperature before inoculation. Berries were wounded once with a sterile nail at the equator portion, inoculated into the wound site with $5 \mu \mathrm{L}$ conidial suspension of $B$. cinerea at the concentration of $10^{6}$ conidia $\mathrm{mL}^{-1}$ on each wound, and left to dry for $2 \mathrm{~h}$. Then $5 \mu \mathrm{L}$ of each salt solution at different concentrations $(0.2,0.4,0.6,0.8$, and $1.0 \%)$ was added to the same wound sites. Berries treated with water served as control. Treated berries were placed in plastic boxes $(20 \times 13 \times 10 \mathrm{~cm})$ and incubated at $23 \pm 1{ }^{\circ} \mathrm{C}$ and high humidity $(90-95 \%)$. Each treatment contained three replicates with 30 fruits each. The entire experiment was repeated twice. The incidence of decay (infected wounds, $\%$ ) and disease severity (lesion diameter, $\mathrm{mm}$ ) were recorded after 4 days of incubation. 


\subsection{Effect of Salts on B. cinerea Radial Growth}

To examine the effect of $\mathrm{PB}, \mathrm{CCh}$, and SSi on the growth of $B$. cinerea, mycelia plugs ( $5 \mathrm{~mm}$ in $\varnothing$ ) from the growing edge of 1-week-old cultures were placed in the center of Petri dishes including potato dextrose agar (PDA) amended with tested salts at final concentrations $0.0,0.1,0.2$, and $0.3 \%$. Salt solutions were filtered through an EPS $0.45 \mu \mathrm{m}$ filter (Millipore Express, Merck Millipore Ltd., Cork Ireland). Each salt/concentration includes five plates as replicates and the whole experiment was repeated twice. The inoculated plates were incubated at $23 \pm 1{ }^{\circ} \mathrm{C}$ and radial fungal growth $(\mathrm{mm})$ of B. cinerea was recorded at $24,48,72$, and $96 \mathrm{~h}$ of incubation. The percentage of reduction in colony diameter $(\mathrm{CD})$ was calculated as

$$
\mathrm{CD}(\%)=(\mathrm{dc}-\mathrm{dt}) / \mathrm{dc} \times 100
$$

where:

$\mathrm{dc}=$ average diameter of linear growth in control

$\mathrm{dt}=$ average diameter of linear growth in salt-treatment

\subsection{Effect of Salts on B. cinerea Conidial Germination and Germ Tube Elongation}

The effect of $\mathrm{PB}, \mathrm{CCh}$, and SSi solutions on B. cinerea on conidial germination (\%) and germ tube elongation $(\mu \mathrm{m})$ was determined according to the standard protocol. Conidial suspension at final concentration $10^{6}$ conidia $\mathrm{mL}^{-1}$ was mixed with tested salts at final concentrations $0.0,0.1,0.2$, and $0.3 \%$ amended with potato dextrose broth (PDB) medium. The mixture was incubated at $23 \pm 1{ }^{\circ} \mathrm{C}$ for $8 \mathrm{~h}$. About 200 conidia were examined for germination rate and germ tube length (Olympus microscope CX41, Japan). Conidia were considered germinated if the germ tube was equal to or greater than the diameter of the conidium [8]. Each treatment includes five replicates and the whole experiment was repeated twice. The percentage of reduction of germinated conidia was calculated as

$$
\text { Reduction }(\%) \text { of germinated conidia }=(\mathrm{gc}-\mathrm{gt}) / \mathrm{gc} \times 100
$$

where:

gc $=$ average germinated conidia in control

$\mathrm{gt}=$ average germinated conidia in salt-treatment

Also, the percentage of reduction of germ tube length was calculated as

$$
\text { Reduction }(\%) \text { of germ tube length }=(\mathrm{gtc}-\mathrm{gtt}) / \mathrm{gtc} \times 100
$$

where:

gtc $=$ average germ tube length in control

$\mathrm{gtt}=$ average germ tube length in salts-treatment

\subsection{Scanning Electron Microscopy (SEM)}

Plugs of $B$. cinerea $(6 \mathrm{~mm}$ in $\varnothing)$ were cut from cultures grown for $96 \mathrm{~h}$ in PDA at $23 \pm 1{ }^{\circ} \mathrm{C}$ treated or not with $\mathrm{PB}, \mathrm{CCh}$, and SSi at $0.2 \%$ and placed in vials containing $3 \%$ glutaraldehyde and $2 \%$ paraformaldehyde in $0.1 \mathrm{M}$ sodium cacodylate buffer ( $\mathrm{pH} 7.2$ ) at $4{ }^{\circ} \mathrm{C}$. Samples were kept in this solution for overnight for fixation and were then washed with $0.1 \mathrm{M}$ sodium cacodylate buffer ( $\mathrm{pH} 7.2)$ for $10 \mathrm{~min}$ three times. Consequently, the samples were dehydrated in an ethanol series (30, 50, 70, 90, and 100\%) for $10 \mathrm{~min}$ three times. Samples were critical point dried with $\mathrm{CO}_{2}$ (BALTEC CPD 030 Critical Point Drier) created with gold (BALTEC SDC 050 Sputter Coater) and observed in a FEI Quanta 200 SEM operating at 25.0 KV [14]. 


\subsection{Transmission Electron Microscopy (TEM)}

Conidial suspension of $B$. cinerea $\left(10^{6}\right.$ conidia $\left.\mathrm{mL}^{-1}\right)$ was mixed with PDB amended with $\mathrm{PB}$, $\mathrm{CCh}$, and SSi at $0.2 \%$ was incubated at $23 \pm 1{ }^{\circ} \mathrm{C}$ for $8 \mathrm{~h}$. PDB mixed with conidium suspension was served as a control. Samples were centrifuged at 6,000 rpm for $10 \mathrm{~min}$ and pellet was fixed in 3\% glutaraldehyde and $2 \%$ paraformaldehyde in $0.1 \mathrm{M}$ sodium cacodylate buffer $(\mathrm{pH} 7.2)$ at $4{ }^{\circ} \mathrm{C}$. Samples were washed with $0.1 \mathrm{M}$ sodium cacodylate buffer ( $\mathrm{pH} 7.2)$ for $15 \mathrm{~min}$ three times. Subsequently, the samples were post-fixed in 1\% osmium tetroxide in $1 \%$ cacodylate buffer, embedded in Araldite resin (Electron microscopy Sciences, Hatfield, PA, USA). Stained $0.5 \mu \mathrm{m}$ sections of TEM blocks were used to select appropriate sections. Ultrathin sections $(60 \mathrm{~nm})$ were obtained by using a ultramicrotome (Leica Ultracut UCT, Solms, Hesse, Germany), transferred to 200 mesh grids, stained with Reynolds' lead citrate solution, then analyzed and photographed using a transmission electron microscope (JEOL, JEM-1400, Japan) at a current HT $80 \mathrm{KV}$ according to [15].

\subsection{Effect of Salt Solutions on Reactive Species of Oxygen (ROS) Generation}

The probe 6-carboxy-2', $7^{\prime}$-dichlorodihydrofluoresce in diacetate, di(acetoxymethyl ester) (Molecular Probes, Inc. Eugene, OR, USA) was used to assess the intracellular ROS production levels in B. cinerea according to the manufacturer's protocol (C2938). One $\mathrm{mL}$ of B. cinerea conidium solution (at a concentration of $10^{6}$ conidia $\left.\mathrm{mL}^{-1}\right)$ was treated with deionized water $\left(\mathrm{dH}_{2} \mathrm{O}\right), \mathrm{PB}, \mathrm{SSi}$, and $\mathrm{CCh}$ at $0.2 \%$, incubated for $8 \mathrm{~h}$ and centrifuged at 6,000 rpm for $10 \mathrm{~min}$. Conidia were washed with $10 \mathrm{mM}$ phosphate buffer saline (PBS) saline ( $\mathrm{pH}$ 7.0) and re-suspended in the same buffer containing $10 \mu \mathrm{M}$ acetoxymethyl ester dye (dissolved in dimethyl sulfoxide, DMSO). The suspension was incubated in the dark at $25^{\circ} \mathrm{C}$ for $1 \mathrm{~h}$. The loading buffer was removed and cells were returned to PBS buffer for $1 \mathrm{~h}$ until acetoxymethyl ester cleavage. Conidia were examined under fluorescent microscope (filter set 09 Zeiss: excitation: BP450-490 nm, emission: LP515 nm) microscope (Zeiss Axio Scope A1, Germany). Each treatment includes three replicates and the whole experiment was repeated twice. Five fields from each slide were randomly chosen; the numbers of conidia stained by acetoxymethyl ester dye in each treatment were calculated. Image capture was accomplished with an AxioCam MRc5 (Carl Zeiss) camera using Axio Vision Rel.4.7.2 software (Carl Zeiss Imaging Solutions $\mathrm{GmbH}$, Germany) with a microscopic field area of $0.9 \mathrm{~mm}$. The ROS production level was calculated as [16]

$\mathrm{RPL}=$ number of fluorescing conidia/number of conidia present in field image $\times 100$.

\subsection{Effect of Salt Solutions on Conidium Mitochondrial Membrane Potential (MMP)}

Loss of the membrane potential $(\Delta \psi \mathrm{m})$ is a hallmark for cellular impairment and was measured with the mitochondrial membrane potential detection MitoProbe ${ }^{\mathrm{TM}}$ JC-1 Assay Kit $\left[\right.$ MitoProbe $^{\mathrm{TM}} \mathrm{JC}-1$ Assay Kit (M34152), Molecular Probes, Inc.], which contained a cationic dye (5, 5' , 6, 6' -tetrachloro-1, 1', 3, 3'-tetraethylbenzimidazolylcarbocyanine iodide) that fluoresced red in the mitochondria of healthy cells, and green in the cytoplasm of cells in which the mitochondria membrane collapsed. The ratio $\mathrm{red} /$ green fluorescence was considered a measure of mitochondria integrity: higher in healthy cells and lower in impaired cells. One $\mathrm{mL}$ of $B$. cinerea conidium solution (at a concentration of $10^{6}$ conidia $\mathrm{mL}^{-1}$ ) was treated with $\mathrm{dH}_{2} \mathrm{O}, \mathrm{PB}, \mathrm{SSi}$, and $\mathrm{CCh}$ at $0.2 \%$, incubated for $8 \mathrm{~h}$ and centrifuge at $6000 \mathrm{rpm}$ for $10 \mathrm{~min}$. B. cinerea conidia were re-suspended in $1 \mathrm{~mL}$ PBS buffer and then were incubated for $5 \mathrm{~min}$ at $37^{\circ} \mathrm{C}$. For the control tube, $1 \mu \mathrm{L}$ of carbonyl cyanide 3-chlorophenylhydrazone (CCCP) was added. Then, $10 \mu \mathrm{L}$ of $200 \mu \mathrm{M} \mathrm{JC}-1$ was added and samples were incubated at $37^{\circ} \mathrm{C}$ for $30 \mathrm{~min}$. Conidia were washed once by adding $2 \mathrm{~mL}$ of PBS, centrifuged $5 \mathrm{~min}$ at 1,000 rpm, and the supernatant was removed. Cell pellet was gently re-suspended in $500 \mu \mathrm{L}$ of PBS. Each treatment includes three replicates and the whole experiment was repeated twice. A fluorescent microscope (Zeiss Axio Scope A1, Germany) with red (546/12 nm excitation and 575-640-nm emission)/green (450-490-nm excitation and 515-nm emission) excitation filter was used to analyze the differential distribution of the red and green forms 
of the dye. The ratio red/green fluorescence was considered a measure of mitochondria integrity (mitochondrial membrane potential (MMP). J-aggregates were detected with the red channel and the monomeric form with the green channel. Images were captured as described above.

\subsection{Effect of Salt Solutions on Adenosine Triphosphate (ATP) Content}

B. cinerea pelleted conidia $\left(10^{8}\right)$ were treated with $\mathrm{dH}_{2} \mathrm{O}, \mathrm{PB}, \mathrm{SSi}$, and $\mathrm{CCh}$ at $0.2 \%$, incubated for $8 \mathrm{~h}$, and centrifuged at 10,000 rpm for $15 \mathrm{~min}$. ATP from treated conidia was extracted with $50 \mu \mathrm{L}$ of $2.5 \%$ trichloroacetic acid (Synth, SP, Brazil) for $3 \mathrm{~h}$ at $4{ }^{\circ} \mathrm{C}$. After centrifugation at 10,000 rpm for $15 \mathrm{~min}$, $10 \mu \mathrm{L}$ of supernatant was diluted with $115 \mu \mathrm{L}$ of ATP-free $\mathrm{H}_{2} \mathrm{O}$ (deionized water) and $125 \mu \mathrm{L}$ of ATP-free 40 mMTris-Acetate buffer ( $\mathrm{pH}$ 8.0) as reported by [17]. For determination of ATP amounts in the extracts, a luciferin/luciferase kit was used (ATP Determination Kit (A22066)) according to the protocol of manufacturer (Molecular Probes, Inc. Eugene, OR, USA). Ten $\mu \mathrm{L}$ of diluted sample was mixed with $90 \mu \mathrm{L}$ of standard reaction solution from the kit. A standard curve was generated for a series of ATP concentrations and the luminescence was measured as arbitrary units. The luminescence emission by the reaction was then determined with a multi-mode detection microplate reader (SynergyTM HT, BioTek Instruments, Inc. USA) at different incubation time (5, 15, 30, and $60 \mathrm{~min})$. Each treatment includes three replicates and the whole experiment was repeated twice. The results were expressed as content of ATP ( $\mu$ moles $/ 10^{8}$ cell).

\subsection{Statistical Analysis}

Data were subjected to ANOVA (one-way analysis of variance) using Statistica 6.0 software. Mean values of treatments were compared by using Fisher's protected least significant difference (LSD) test and judged $p \leq 0.05$ level. When applicable, percentage data were arcsine-square root transformed in order to normalize variance.

\section{Results and Discussion}

\subsection{Effect of Salts on Gray Mold Disease}

Decay incidence and severity were recorded after 4 days of incubation. Generally, the efficacy of salts was positively correlated with the concentration. As concentration of salts increased, disease incidence decreased. For decay incidence and severity, application of $1.0 \% \mathrm{~PB}, 0.8 \% \mathrm{SSi}$, and $0.8 \% \mathrm{CCh}$ completely inhibited gray mold incidence on grape berries (Figures 1 and 2). For decay incidence, $\mathrm{PB}$ at $0.8 \%$ reduced the incidence of disease by $63 \%$ as compared to control. No significance differences were found between the three tested salts at $0.4,0.6$, and $1.0 \%$. For decay severity, PB at $0.8 \%$ reduced the lesion diameter by $58 \%$ as compared to control. No significance difference was found between salts at $0.2 \%$ as compared to control (Figure 3 ). The results obtained herein confirm our previous ones on 'Italia' and 'Benitaka' table grapes [3,4]. Aqueous solutions $(1.0 \%, \mathrm{w} / \mathrm{v})$ of CCh, PB, and SSi reduced the occurrence of gray mold by 90,80 , and $89 \%$, respectively as compared to the water control in immersion methods. In another study, a reduction of Botrytis incidence $(23 \%)$ was obtained with sodium silicate as compared to control [7]. Qin et al. [8] concluded that decay incidence of gray mold was lower that $5 \%$ when $1 \%$ of boron was used. Recently, the effect of natamycin on inoculated grape berries was evaluated [5] and $50 \mathrm{mg} \mathrm{L}^{-1}$ reduced the lesion diameter of gray mold by $77 \%$ compared to control, while $100 \mathrm{mg} \mathrm{L}^{-1}$ completely inhibited the occurrence of mold. 


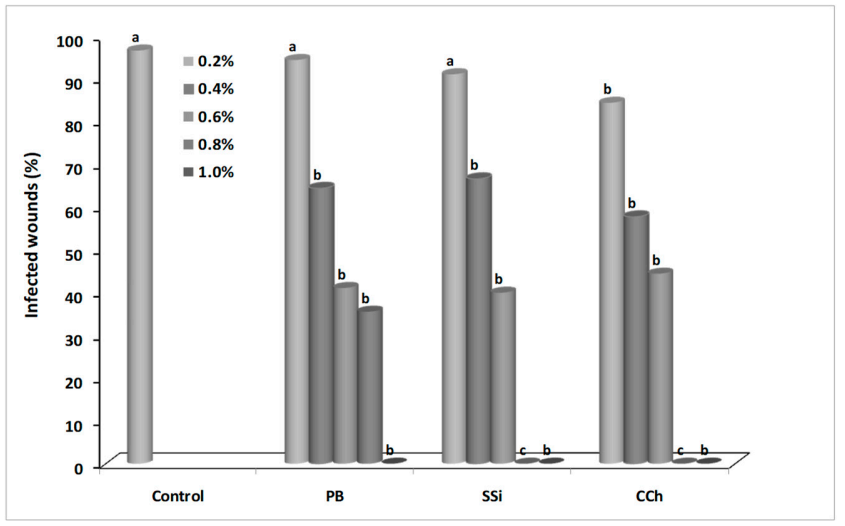

Figure 1. Decay incidence (\% infected wounds) caused by Botrytis cinerea on 'Italia' table grapes untreated or treated with different concentration of potassium bicarbonate (PB), sodium silicate (SSi), and calcium chelate $(\mathrm{CCh})$ after 4 days of incubation at $23 \pm 1{ }^{\circ} \mathrm{C}$. Values marked with the same letters are not statistically different by Fisher's protected least significant difference test at $p \leq 0.05$.

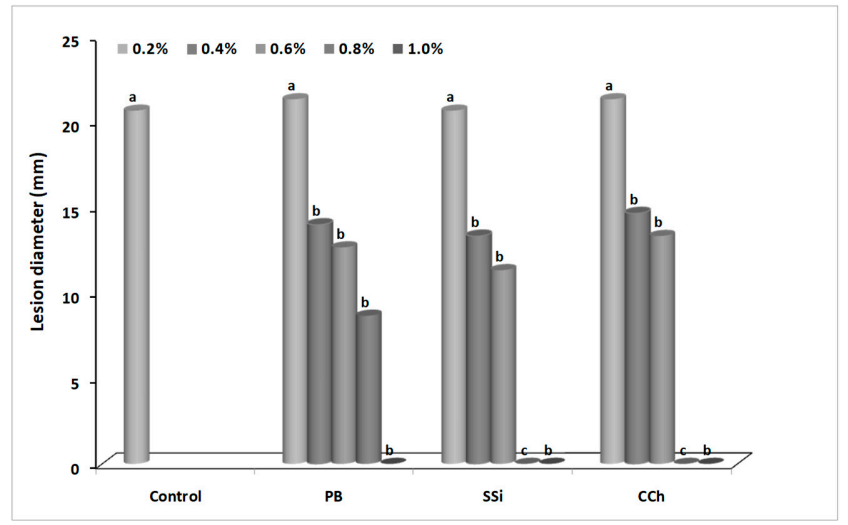

Figure 2. Decay severity (lesion diameter, $\mathrm{mm}$ ) caused by Botrytis cinerea on 'Italia' table grapes untreated or treated with different concentration of potassium bicarbonate (PB), sodium silicate (SSi), and calcium chelate $(\mathrm{CCh})$ after 4 days of incubation at $23 \pm 1{ }^{\circ} \mathrm{C}$. Values marked with the same letters are not statistically different by Fisher's protected least significant difference test at $p \leq 0.05$.

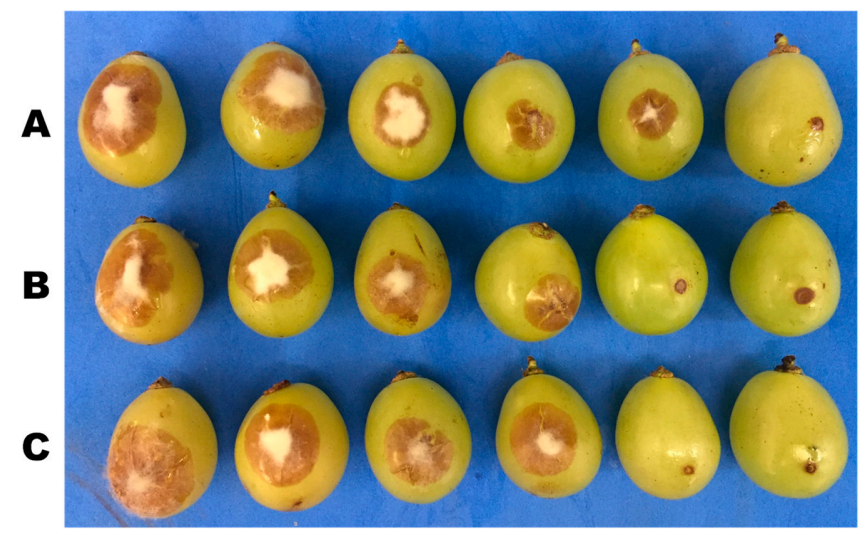

Figure 3. Effect of five concentrations of potassium bicarbonate (PB), sodium silicate (SSi), and calcium chelate $(\mathrm{CCh})$ on gray mold disease of grapes. (A) Berries inoculated with Botrytis cinerea (10 6 conidia $\mathrm{mL}^{-1}$ ) and treated with PB at 0.0, 0.2, 0.4, 0.6, 0.8, and 1.0\% from left to right respectively. (B) Berries inoculated with B. cinerea conidial suspension and treated with SSi at $0.0,0.2,0.4,0.6,0.8$, and $1.0 \%$ respectively. $(C)$ Berries inoculated with $B$. cinerea conidium suspension and treated with $\mathrm{CCh}$ at 0.0 , $0.2,0.4,0.6,0.8$, and $1.0 \%$ respectively. 


\subsection{Effect of Salts on B. cinerea Radial Growth}

The mycelial growth of $B$. cinerea was measured daily and the inhibition was positively correlated with the concentration of salts. The vegetative growth of $B$. cinerea was completely inhibited on the plate with $0.3 \%$ of $\mathrm{PB}, \mathrm{SSi}$, and $\mathrm{CCh}$. After $96 \mathrm{~h}$ of incubation, the growth rate was decreased by 57 and $79 \%$ under the action of 0.1 and $0.2 \% \mathrm{~PB} ; 65$ and $80 \%$ of 0.1 and $0.2 \% \mathrm{SSi} ; 39$ and $73 \%$ of 0.1 and $0.2 \%$ CCh, respectively (Table 1 and Figure 4). The results obtained herein confirmed other findings on antifungal activity salts against several plant pathogenic fungi. Youssef and Roberto [3,4] showed that $\mathrm{PB}, \mathrm{CCh}$, and SSi completely inhibited mycelial growth of $B$. cinerea at $0.25 \%$. In the same way, sodium silicate at $100 \mathrm{mM}$ completely suppressed the growth of Trichothecium roseum in vitro tests [18]. A significant reduction (up to $30 \%$ ) of Penicillium digitatum growth was observed also in presence of sodium bicarbonate [16]. Also, Bi et al. [19] observed that the mycelial growth of Alternaria alternata, Fusarium semitectum, and $T$. roseum decreased significantly with increasing concentration of sodium silicate in vitro. Newly, the vegetative growth of $B$. cinerea was completely inhibited with $2 \mathrm{mg} \mathrm{L}^{-1}$ of natamycin on PDA plates [5].

Table 1. Effect of three concentrations of potassium bicarbonate (PB), sodium silicate (SSi), and calcium chelate (CCh) amended with PDA on the mycelial growth of Botrytis cinerea.

\begin{tabular}{lllll}
\hline \multirow{2}{*}{ Salts } & \multicolumn{4}{c}{ Mycelial Growth (mm) } \\
\cline { 2 - 5 } & $\mathbf{2 4} \mathbf{h}$ & $\mathbf{4 8 ~ h}$ & $\mathbf{7 2} \mathbf{~ h}$ & $\mathbf{9 6} \mathbf{~ h}$ \\
\hline Control & $19.2 \mathrm{a}$ & $38.8 \mathrm{a}$ & $60.8 \mathrm{a}$ & $79.2 \mathrm{a}$ \\
PB 0.1\% & $13.2 \mathrm{~b}$ & $18.0 \mathrm{c}$ & $29.2 \mathrm{c}$ & $34.0 \mathrm{c}$ \\
PB 0.2\% & $10.8 \mathrm{~d}$ & $13.6 \mathrm{e}$ & $14.8 \mathrm{f}$ & $16.8 \mathrm{f}$ \\
PB 0.3\% & $0.0 \mathrm{e}$ & $0.0 \mathrm{f}$ & $0.0 \mathrm{~g}$ & $0.0 \mathrm{~g}$ \\
SSi 0.1\% & $12.8 \mathrm{bc}$ & $15.6 \mathrm{~d}$ & $23.2 \mathrm{~d}$ & $27.2 \mathrm{~d}$ \\
SSi 0.2\% & $10.4 \mathrm{~d}$ & $12.8 \mathrm{e}$ & $14.4 \mathrm{f}$ & $15.6 \mathrm{f}$ \\
SSi 0.3\% & $0.0 \mathrm{e}$ & $0.0 \mathrm{f}$ & $0.0 \mathrm{~g}$ & $0.0 \mathrm{~g}$ \\
CCh 0.1\% & $18 \mathrm{a}$ & $32.8 \mathrm{~b}$ & $41.6 \mathrm{~b}$ & $48.0 \mathrm{~b}$ \\
CCh 0.2\% & $11.6 \mathrm{~cd}$ & $18.8 \mathrm{c}$ & $20.4 \mathrm{e}$ & $21.2 \mathrm{e}$ \\
CCh 0.3\% & $0.0 \mathrm{e}$ & $0.0 \mathrm{f}$ & $0.0 \mathrm{~g}$ & $0.0 \mathrm{~g}$ \\
\hline
\end{tabular}

Colony diameter was assessed daily at $23 \pm 1{ }^{\circ} \mathrm{C}$. Statistical analysis was performed within each column. Values marked with the same letters are not statistically different by Fisher's protected least significant difference test at $p \leq 0.05$.

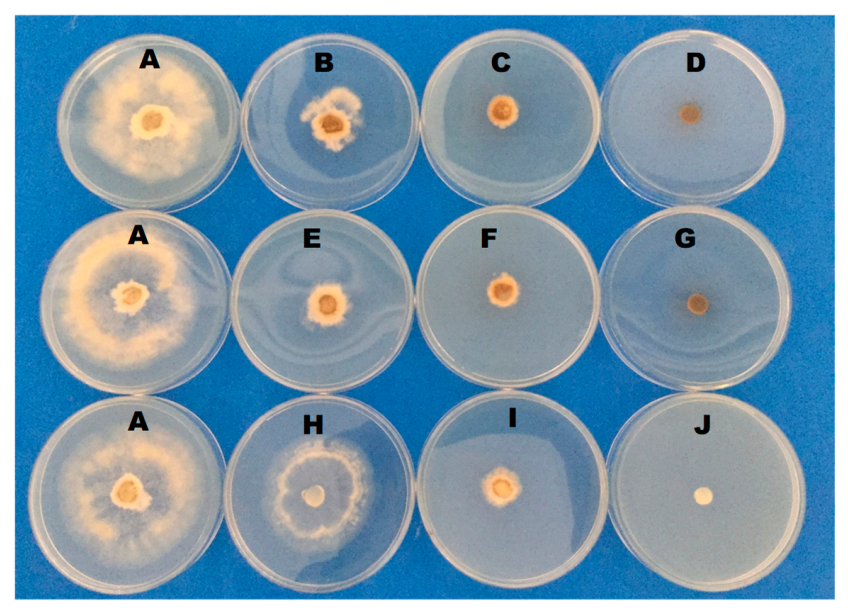

Figure 4. Effect of three concentrations of potassium bicarbonate (PB), sodium silicate (SSi), and calcium chelate (CCh) amended with PDA on the mycelial growth of Botrytis cinerea after $96 \mathrm{~h}$ of incubation at $23 \pm 1{ }^{\circ} \mathrm{C}$. (A) Control; (B-D) PB at 0.1, 0.2, 0.3\% respectively; (E-G) SSi at 0.1, 0.2, $0.3 \%$ respectively; $(\mathbf{H}-\mathrm{J}) \mathrm{CCh}$ at $0.1,0.2,0.3 \%$ respectively. 


\subsection{Effect of Salts on B. cinerea Conidial Germination and Germ Tube Elongation}

The inhibitory effect of salts on conidium germination and germ tube elongation of $B$. cinerea was shown in Figures 5 and 6. Conidia germination and germ tube elongation were completely inhibited by $\mathrm{PB}, \mathrm{SSi}$, and $\mathrm{CCh}$ at $0.3 \%$. After $8 \mathrm{~h}$ of incubation, the germination rate was decreased by 11 and $51 \%$ under the action of 0.1 and $0.2 \% \mathrm{~PB} ; 38$ and $69 \%$ of 0.1 and $0.2 \% \mathrm{SSi} ; 22$ and $47 \%$ of 0.1 and $0.2 \%$ $\mathrm{CCh}$, respectively (Figure 5). The direct activity of salts is well known [3,4,20-30] in inhibiting conidial germination, germ tube elongation, and production of pectinolytic enzymes in several pathogens. B. cinerea conidia immersed in solution of $\mathrm{PB}, \mathrm{CCh}$, and SSi at $0.25 \%$ completely inhibited conidia germination by $100 \%[3,4]$. Several salts counting potassium tetraborate, calcium chloride, sodium carbonate, and sodium bicarbonate have been tested for their effectiveness to control gray mold, in small- and large-scale experiments $[7,8,26]$. Conidial germination and germ tube elongation were completely inhibited by boron at $0.5 \%$ and conidium germination was less sensitive to boron than germ tube elongation [8]. We noted that vegetative growth, conidial germination, and germ tube elongation of $B$. cinerea were more sensitive to SSi than PB or CCh at the same concentration. Our results were in agreement with Liu et al. [31] who demonstrated that conidial germination, germ tube elongation, and mycelial growth of $P$. digitatum were inhibited by sodium silicate at $0.1 \%$ (conidial germination) and $0.5 \%$ (mycelial growth). Also, sodium bicarbonate inhibited conidial germination of P. digitatum by $75 \%$ as compared to control and a similar effect was observed on germ tube elongation after 15 min of treatment [16]. In our study, a correlation was observed between results from artificial berry inoculations and in vitro tests, as salt treatments reduced disease incidence and severity, and inhibited pathogen growth and conidial germination. These results are in agreement with previous findings [3,4].

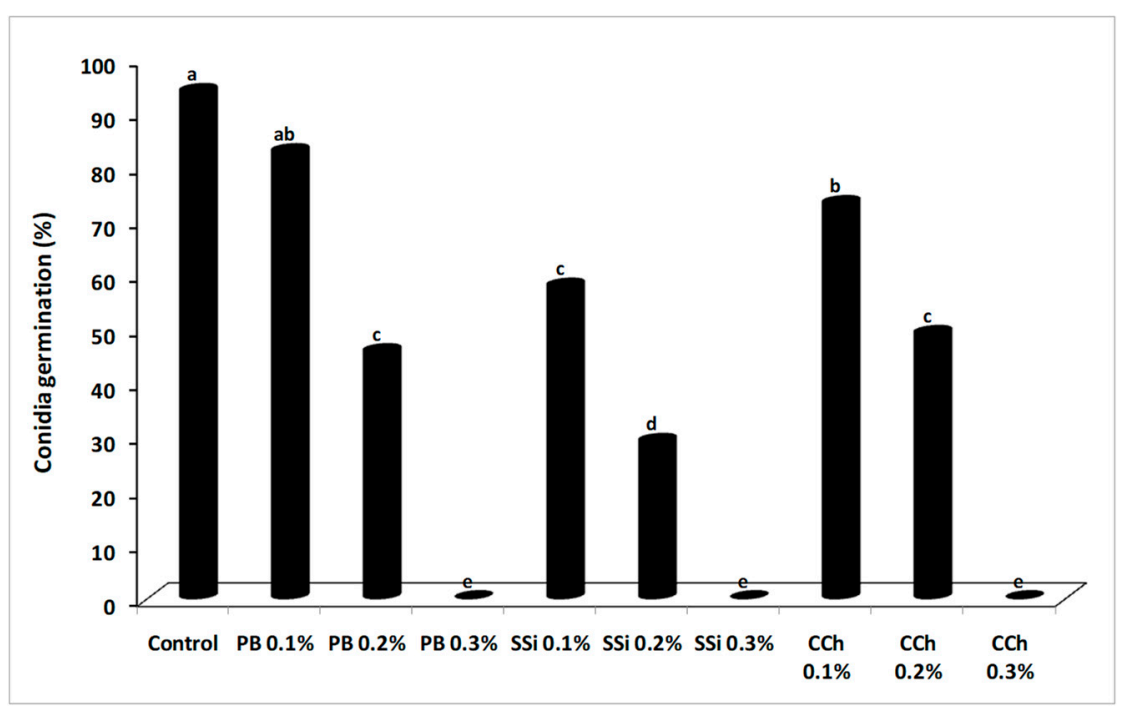

Figure 5. Effect of potassium bicarbonate (PB), sodium silicate (SSi), and calcium chelate (CCh) on conidial germination (\%) of Botrytis cinerea in potato dextrose broth after $8 \mathrm{~h}$ of incubation at $23 \pm 1{ }^{\circ} \mathrm{C}$. Values marked with the same letters are not statistically different by Fisher's protected least significant difference test at $p \leq 0.05$. 


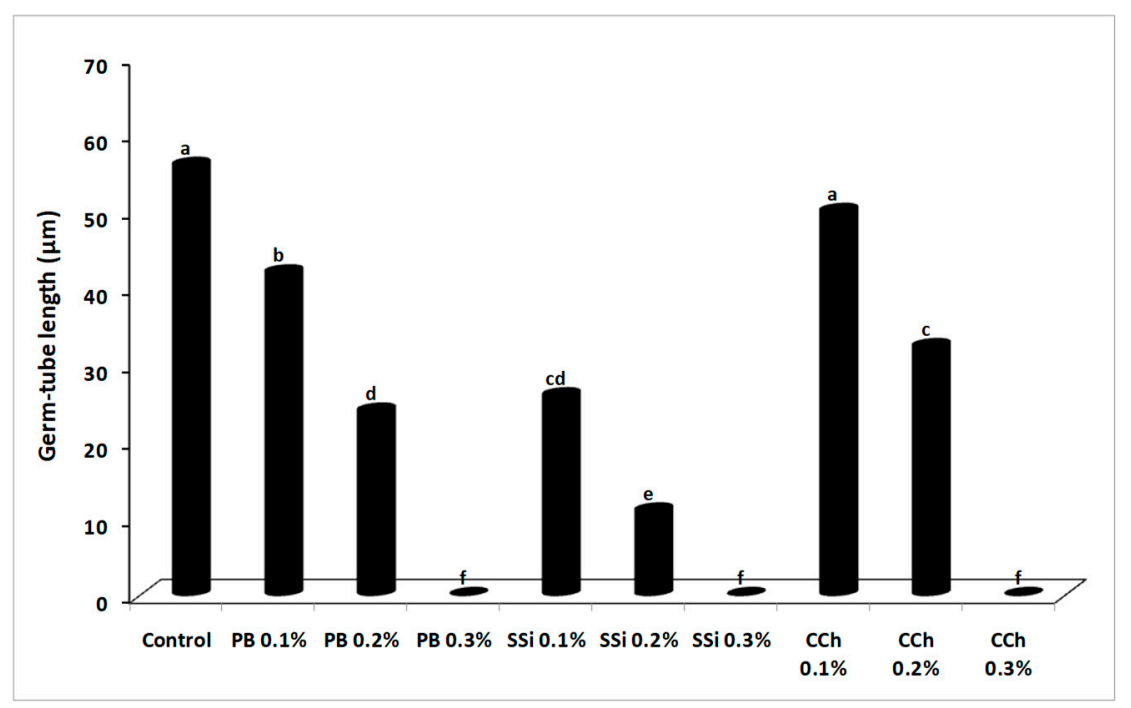

Figure 6. Effect of potassium bicarbonate (PB), sodium silicate (SSi), and calcium chelate (CCh) on germ tube elongation $(\mu \mathrm{m})$ of Botrytis cinerea in potato dextrose broth after $8 \mathrm{~h}$ of incubation at $23 \pm 1{ }^{\circ} \mathrm{C}$. Values marked with the same letters are not statistically different by Fisher's protected least significant difference test at $p \leq 0.05$.

\subsection{Scanning Electron Microscopy (SEM)}

Morphological damage was detected in the hyphae treated with $\mathrm{PB}, \mathrm{SSi}$, and CCh compared to the hyphae in the control. Shriveled hyphae were commonly observed in salt-treated mycelia compared with the control-normal mycelia. Control demonstrating hyphae with typical 'net' structure and smooth surface while salt-treated hyphae lost their smoothness and formed unusual bulges on its surface. Defects such as malformation and excessive septation were detected on salt-treated hyphae morphology (Figure 7). SEM was previously used to demonstrate the morphology alternation of fungal hyphae, especially $B$. cinerea due to the treatment with various compounds. The direct examination by SEM indicated that the high concentration of nanoscale silicate $\left(1000 \mathrm{mg} \mathrm{L}^{-1}\right)$ could cause conidium and mycelia shrinkages of B. cinerea [32]. Also, silver nanoparticles caused Quercus wilting and damaged the mycelia of Raffaelea sp. [33] or Colletotrichum acutatum [34]. ZnO nanoparticles caused the defects for mycelia of B. cinerea and conidiophore of Penicillium expansum based on SEM inspection [35]. Similarly, SEM analysis showed that fludioxonil + metalaxyl-M caused inhibition of hyphal growth and defects on hyphae morphology of Fusarium verticillioides [36]. Recently, application of chitosan and silica nanoparticles caused asymmetrical branching of B. cinerea hyphae in the apical branch and the failure of linearity [37]. 


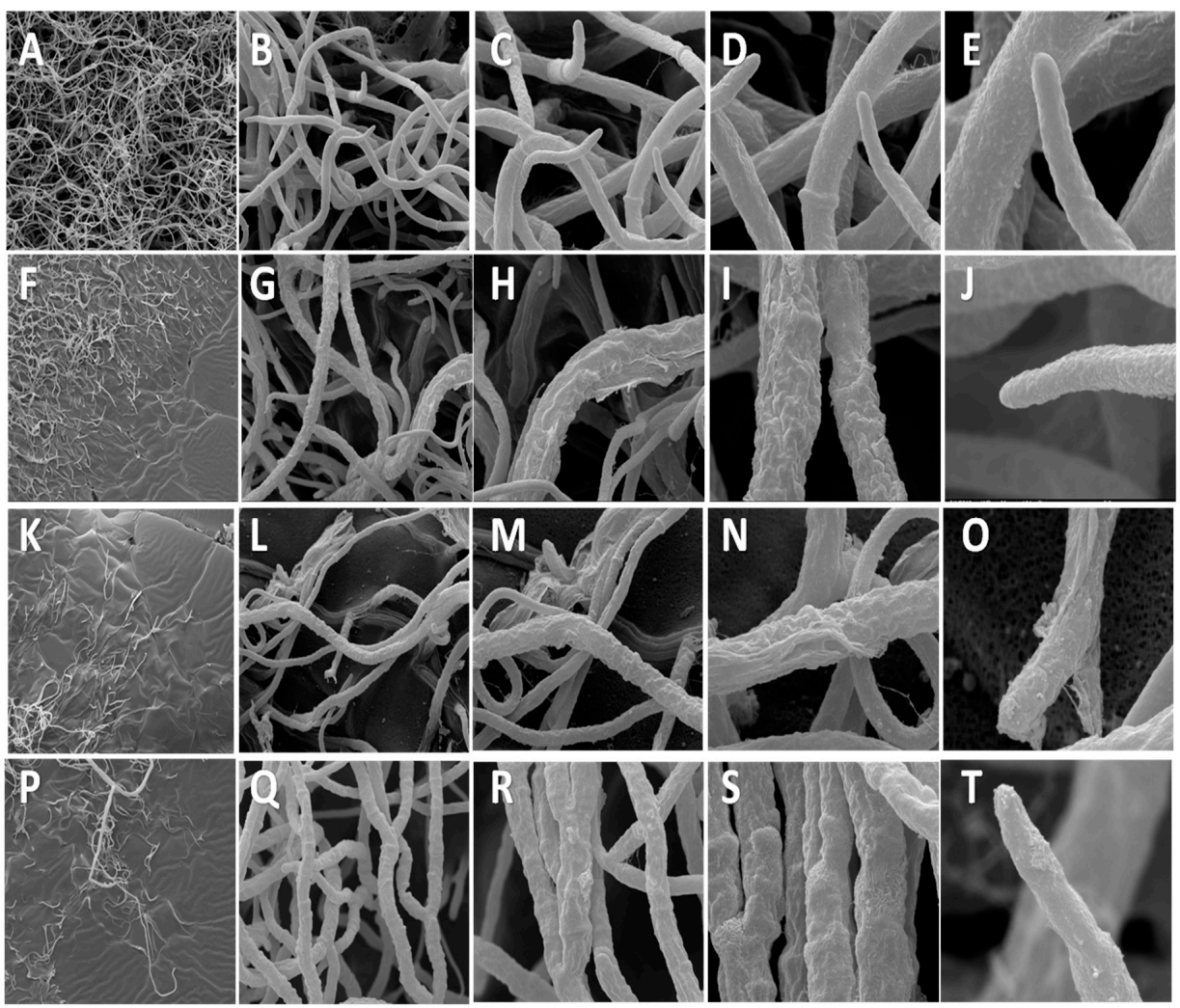

Figure 7. Scanning electron microscopy images of antifungal effect of salts against Botrytis cinerea. (A-E) Control after $96 \mathrm{~h}$ after incubation; (F-J) treatment with potassium bicarbonate (PB) at $0.2 \%$; $(\mathrm{K}-\mathrm{O})$ treatment with sodium silicate $(\mathrm{SSi})$ at $0.2 \%$; $(\mathbf{P}-\mathbf{T})$ treatment with calcium chelate $(\mathrm{CCh})$ at $0.2 \%$. In the magnitude of $400 \times(\mathrm{A}-\mathrm{P}$; bar 300 $\mu \mathrm{m}), 3000 \times(\mathrm{B}-\mathrm{Q}$; bar $20 \mu \mathrm{m}), 6000 \times(\mathrm{C}-\mathrm{R}$; bar $20 \mu \mathrm{m}), 12,000 \times$ (D-S; bar $10 \mu \mathrm{m})$ and 24,000× (E-T; bar $5 \mu \mathrm{m})$.

\subsection{Transmission Electron Microscopy (TEM)}

The images produced by TEM showed the internal structure of $B$. cinerea conidia treated or not with salt solutions at $0.2 \%(w / v)$ (Figure 8$)$. In untreated conidia (Figure $8 \mathrm{~A}-\mathrm{C}$ ), conidia presented normal ultra-structures. In particular, normal cell, cytoplasm, and mitochondria were obvious and appeared normal in morphology. Also, the nuclei were visible with their well-defined envelopes. Conidium outer and inner cell wall showed no defects and was well-organized. In treated conidia, generally, most of the conidia were affected and cellular vacuolization and cytoplasmic disorganization was observed. When the conidia were treated with PB (Figure 8D-F), plasma membrane was fragmented and broken in many places and plasmolysis state showing the ruptured plasma membrane. Also, abnormal distribution and degradation of mitochondria in PB-treated conidia was noted. In SSi-treated conidia (Figure 8G-I), the cytoplasm was retracted and the cell wall was thinner than normal. Compared to untreated conidia, no recognized cellular structures were visible and cytoplasm was disorganized and withdrawn. In case of CCh-treated conidia, the dispersed cytoplasm was mixed with empty areas or vacuoles (Figure 8J-L). Also, the content of conidia appeared degraded and degradation of mitochondria was observed. In addition, severe void spaces were visible in the cell periphery and numerous vacuoles and spheric vesicles were observed. It was noted that the cell wall was opened and cytoplasm leakage was found out of the cell.

Based on the results obtained by TEM, it is believed that salts act directly on the conidia of B. cinerea leading to mitochondrial damage and reducing the infection rate of the fungus. It is well known that the mitochondrial respiratory chain is the major endogenous source of ROS, particularly when the mitochondria are damaged [38]. Correspondingly, when B. cinerea conidia treated with pterostilbene, disorganization, and coagulation of the cytoplasm and its withdrawal from the conidium 
wall, as observed by Pezet and Pont [39]. Our results are in agreement with those of Avis et al. [40] who detected abnormal mitochondria in Fusarium sambucinum and Heterobasidion annosum conidia treated with aluminum chloride and sodium metabisulfite, and included membrane retraction, undulation, and invagination. Therefore, it suggests that mitochondrial degradation of fungal conidia may be one of the important modes by which antifungal compounds inhibit fungal growth. Similarly, TEM was used to observe the plasma membrane disruption and cytoplasmic and mitochondrial disorganization of Geotrichum citri-aurantii and Aspergillus niger conidia treated with essential oils [41,42].

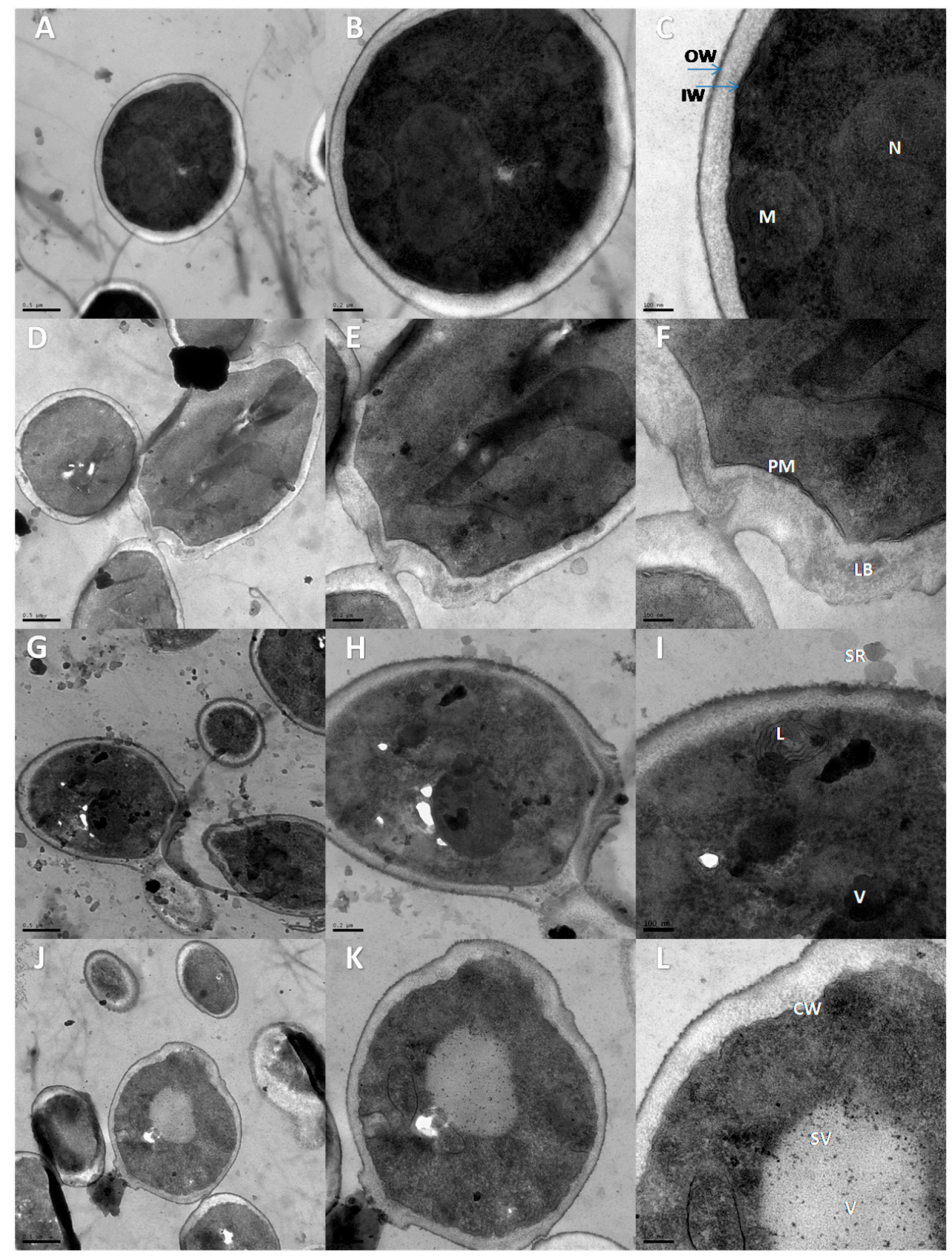

Figure 8. Transmission electron microscopy images show the internal structure of Botrytis cinerea conidia treated or not with salt solutions. (A-C) Control after $8 \mathrm{~h}$ after incubation; (D-F) treatment with potassium bicarbonate $(\mathrm{PB})$ at $0.2 \%$; (G-I) treatment with sodium silicate $(\mathrm{SSi})$ at $0.2 \%$; (J-L) treatment with calcium chelate (CCh) at $0.2 \%$. In the magnitude of $20 \mathrm{k}(\mathrm{A}, \mathrm{D}, \mathrm{G}, \mathrm{J}$; bar $0.5 \mu \mathrm{m}), 40 \mathrm{k}(\mathrm{B}, \mathrm{E}, \mathrm{H}, \mathrm{K}$; bar $0.2 \mu \mathrm{m}), 80 \mathrm{k}$ (C, F, I, L; bar $100 \mathrm{~nm}$ ). M: mitochondria, N: nucleus, LB: liposome-like bodies, L: lomasome, SV: spheric vesicles, IW: inner wall layer of conidium, OW: outer wall layer, V: vacuole, PM: plasma membranee, CW: cytoplasmic withdrawal. 


\subsection{Effect of Salt Solutions on Reactive Species of Oxygen (ROS) Generation}

Reactive species of oxygen accumulation in B. cinerea conidia due to PB, SSi, and CCh was detected in terms of fluorescence emission, and the results showed that a higher number of fluorescent conidia was observed in presence of salt treatment as compared to the control (Figure 9). A higher increase in fluorescent conidia was observed in presence of $\mathrm{PB}, \mathrm{SSi}$, and CCh by 75, 68, and 70\% as compared to control, respectively. Statistically, there was no significant different among the effect of salts itself. A considerable raise of ROS in treated P. digitatum conidia treated with electrolyzed sodium bicarbonate was recorded [16] which confirm our results. ROS could be in charge for pathogen inactivation and direct oxidation at the anode surface of organic compounds [43]. Also, under special stress conditions, high quantities of intracellular ROS are produced [44]. The production of ROS including superoxide anion and hydrogen peroxide can lead to death of the pathogen, by interfering with the pathogen life cycle, and causing numerous structural alterations. In presence of heat and $\mathrm{H}_{2} \mathrm{O}_{2}$, an increased production of ROS in Monilia fructicola and Penicillium expansum conidia, respectively was observed $[45,46]$. In addition, borate application stimulates ROS accumulation in Colletotrichum gloeosporioides conidia and resulting in mitochondrial harm [47]. Similarly, relative ROS levels were increased when $B$. cinerea conidia were treated with tea tree oil or methyl thujate $[48,49]$.

A

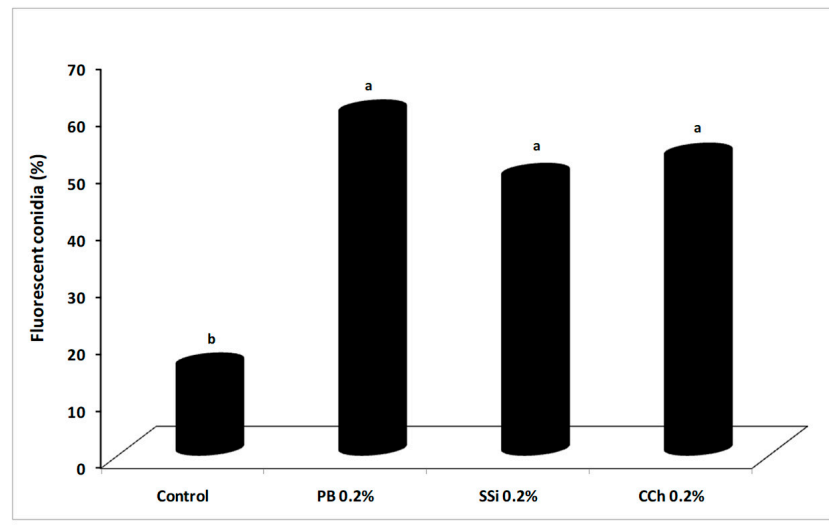

B

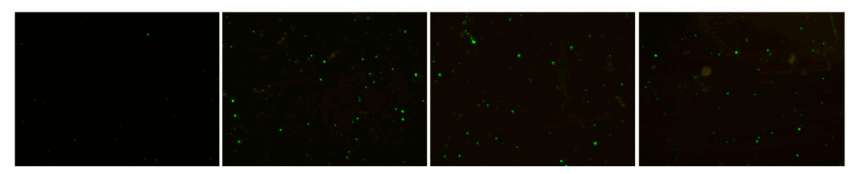

Figure 9. (A) Effect of potassium bicarbonate (PB), sodium silicate (SSi), and calcium chelate (CCh) at $0.2 \%$ on intracellular reactive species of oxygen (ROS) accumulation in Botrytis cinerea. ROS production level expressed as fluorescent conidia (\%). Values marked with the same letters are not statistically different by Fisher's protected least significant difference test at $p \leq 0.05$. (B) Representative images of conidia from different treatments stained with acetoxymethyl ester probe under fluorescence microscopy were showed with a microscopic field area of $0.9 \mathrm{~mm}$.

\subsection{Effect of Salt Solutions on Conidium Mitochondrial Membrane Potential (MMP)}

The ratio of red/green fluorescence is proportional to MMP, the higher the ratio, the more MMP in B. cinerea conidia. MMP was significantly decreased after salt application indicating a loss of mitochondria function. When $B$. cinerea conidia were treated with $\mathrm{PB}, \mathrm{SSi}$, and $\mathrm{CCh}$ the reduction of $\mathrm{red} /$ green fluorescence ratio reached 78,88 , and $81 \%$, respectively. Also, no significant different among the salts was observed (Figure 10). It is well known that MMP is used as a marker of mitochondrial health, since this determine of ion transfer reveals metabolic action and integrity of the mitochondrial membrane. Our results obtained herein are in agreement with Fallanaj et al. [16] who demonstrated that the reduction of MMP was more than $61 \%$ on P. digitatum conidia exposed to electrolyzed sodium bicarbonate. The protection of MMP is linked with several mitochondrial functions especially ATP production [50]. Moreover, levels of mitochondrial dysfunction have been noted to closely follow 
intracellular ROS increase indicating some changes in mitochondria integrity and functionality [51]. Recently, He et al. [5] indicated that natamycin can damage the plasma membrane of $B$. cinerea and P. expansum, resulting the discharge of intracellular contents and eventual cell death.

A

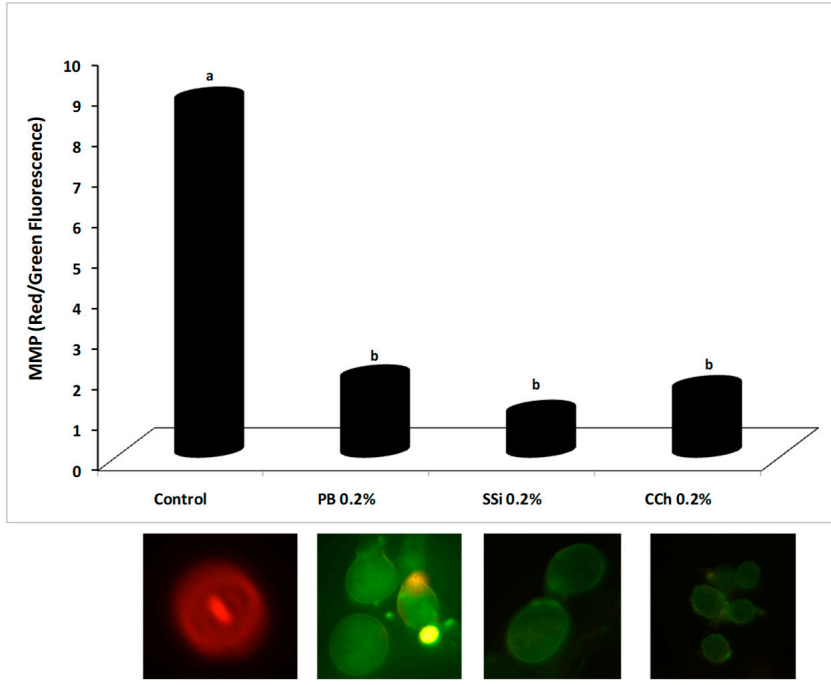

Figure 10. (A) Effect of potassium bicarbonate (PB), sodium silicate (SSi), and calcium chelate (CCh) at $0.2 \%$ on mitochondrial membrane potential (MMP) of Botrytis cinerea conidia represented as red/green florescence ratio and detected by MitoProbe ${ }^{\mathrm{TM}} \mathrm{JC}-1$ Assay Kit. Values marked with the same letters are not statistically different by Fisher's protected least significant difference test at $p \leq 0.05$. (B) For each treatment representative images of stained conidia under fluorescence microscopy were showed.

\subsection{Effect of Salt Solutions on ATP Content}

The changes in ATP content were shown in Figure 11. Data showed that B. cinerea conidia treated with salts contained less ATP than un-treated control. Luminescence was measured after 5, 15, 30, and 60 min of incubation. After 15 min, ATP ( $\mu$ moles $/ 10^{8}$ conidia) was $265,73,123$, and 106 for untreated conidia, $\mathrm{PB}, \mathrm{SSi}$, and $\mathrm{CCh}$ treated conidia, respectively. In particular, $\mathrm{PB}, \mathrm{SSi}$, and $\mathrm{CCh}$ reduced the ATP content by 72,51 , and $58 \%$, respectively as compared to untreated conidia. Also, ATP content of conidia was decreased over incubation time. Obviously, mitochondria are the key basis of energy in eukaryotic cells, generating ATP throughout oxidative phosphorylation and the citric acid cycle [50]. Our results are in agreement with Fallanaj et al. [16] who confirmed that a decreased level of ATP in P. digitatum conidia treated by electrolyzed sodium bicarbonate was observed. Oxidative stress, associated with increased intracellular ROS, resulted in a mitochondrial membrane potential collapse, ATP decrease, and postponed growth [16]. Mitochondrial membrane permeability of $B$. cinerea cells was increased by tea tree oil application, as indicated by a decrease in intracellular ATP and an increase in extracellular ATP content [48]. Understanding the mechanism of action of salts will help to improve them to control postharvest decays and to disinfect fresh products which are derived by economic and consumer demand incentives. The results obtained on this study are mainly interesting for a successful marketable application of alternative control means such as salts to manage pre-postharvest gray mold of fruits and vegetables especially grapes. 


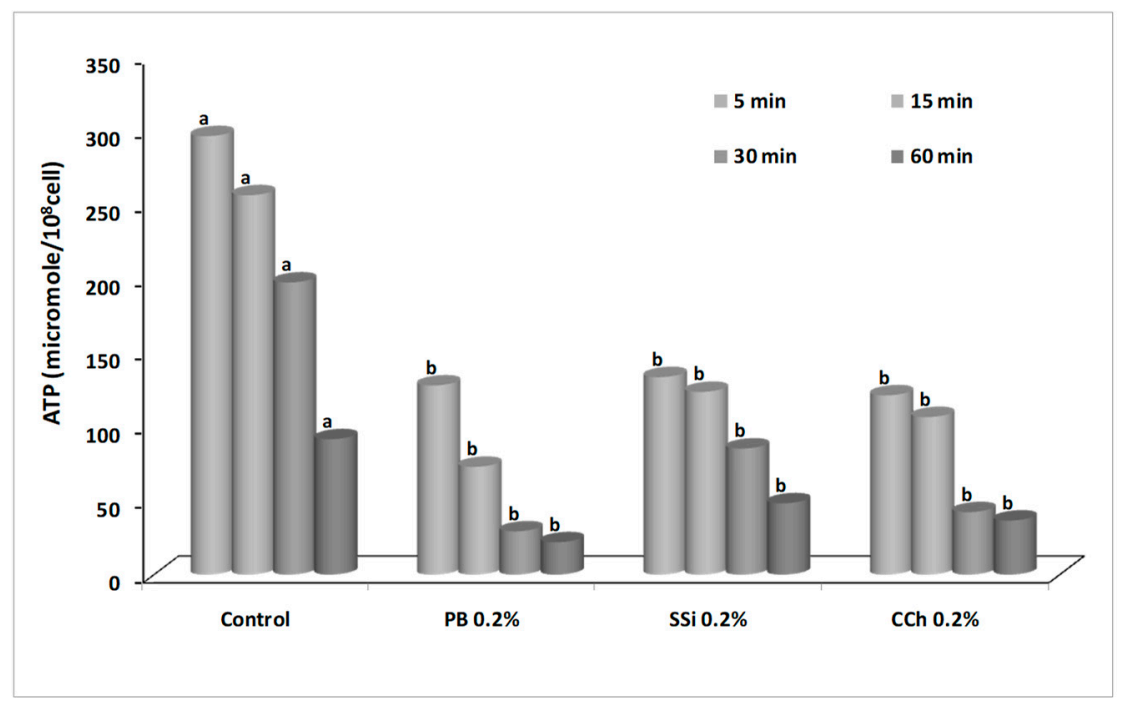

Figure 11. Effect of potassium bicarbonate (PB), sodium silicate (SSi), and calcium chelate (CCh) at $0.2 \%$ on ATP content of Botrytis cinerea conidia determined by luciferin/luciferase kit. The luminescence emission by the reaction was determined with a multi-mode detection microplate reader at different incubation time $(5,15,30$, and $60 \mathrm{~min})$. Values marked with the same letters are not statistically different by Fisher's protected least significant difference test at $p \leq 0.05$.

\section{Conclusions}

In conclusion, our research showed that salts such as potassium bicarbonate, sodium silicate, and calcium chelate can alter the morphology and function of mitochondria in B. cinerea. Those salts caused accumulation of ROS, reduced ATP content, and decreased MMP resulting in the loss of mitochondria function. A correlation between results from artificial berry inoculations and in vitro tests was observed confirming parallels between in vitro and in planta conditions. The results obtained herein are a step towards a comprehensive understanding of the mode of action by which salts act as antifungal agents against $B$. cinerea. Host-pathogen transcriptome profiling could provide an additional useful tool to improve our knowledge about the direct and indirect effects of salt treatments on disease suppression.

Author Contributions: Conceptualization, K.Y. and S.R.R.; Methodology, K.Y.; Software, K.Y.; Validation, K.Y., S.R.R., and A.G.d.O.; Formal analysis, K.Y.; Investigation, K.Y. and S.R.R.; Resources, S.R.R. and A.G.d.O.; Data curation, K.Y., S.R.R., and A.G.d.O.; Writing-original draft preparation, K.Y. and S.R.R.; Writing-review and editing, S.R.R. and A.G.d.O.; Visualization, S.R.R. and A.G.d.O.; Supervision, S.R.R.; Project administration, S.R.R.; Funding acquisition, K.Y. and A.G.d.O.

Funding: This research was funded by Brazilian Council for Scientific and Technological Development (CNPq), grant number 315844/2018-3 and the article processing charges (APC) was funded by Londrina State University.

Acknowledgments: The authors are grateful for the financial support provided by Brazilian Council for Scientific and Technological Development (CNPq) grant No. 315844/2018-3 to Khamis Youssef. A.G. de Oliveira was supported by a research fellowship from CNPq grant No. 315593/2018-0. The authors also thank Thiago Fernandes, Osvaldo Capello, and Danielle Lazarin for their help to carry out SEM and TEM studies.

Conflicts of Interest: The authors declare no conflict of interest.

\section{References}

1. FAOSTAT. Available online: http://www.fao.org/faostat/en/\#data/QC (accessed on 21 August 2019).

2. Dean, R.; Van Kan, J.A.; Pretorius, Z.A.; Hammond-Kosack, K.E.; Di Pietro, A.; Spanu, P.D.; Rudd, J.J.; Dickman, M.; Kahmann, R.; Ellis, J.; et al. The top 10 fungal pathogens in molecular plant pathology. Mol. Plant Pathol. 2012, 13, 414-430. [CrossRef] [PubMed]

3. Youssef, K.; Roberto, S.R. Applications of salt solutions before and after harvest affect the quality and incidence of postharvest gray mold of 'Italia' table grapes. Postharv. Biol. Technol. 2014, 87, 95-102. [CrossRef] 
4. Youssef, K.; Roberto, S.R. Salt strategies to control Botrytis mold of 'Benitaka' table grapes and to maintain fruit quality during storage. Postharv. Biol. Technol. 2014, 95, 95-102. [CrossRef]

5. He, C.; Zhang, Z.; Li, B.; Xu, Y.; Tian, S. Effect of natamycin on Botrytis cinerea and Penicillium expansum-Postharvest pathogens of grape berries and jujube fruit. Postharv. Biol. Technol. 2019, 151, 134-141. [CrossRef]

6. Jacometti, M.A.; Wratten, S.D.; Walter, M. Review: Alternatives to synthetic fungicides for Botrytis cinerea management in vineyards. Aus. J. Grape Wine Res. 2010, 16, 154-172. [CrossRef]

7. Nigro, F.; Schena, L.; Ligorio, A.; Pentimone, I.; Ippolito, A.; Salerno, M.G. Control of table grape storage rots by pre-harvest applications of salts. Postharv. Biol. Technol. 2006, 42, 142-149. [CrossRef]

8. Qin, G.; Zong, Y.; Chen, Q.; Hua, D.; Tian, S. Inhibitory effect of boron against Botrytis cinerea on table grapes and its possible mechanisms of action. Int. J. Food Microbiol. 2010, 138, 145-150. [CrossRef]

9. Alaoui, F.T.; Askarne, L.; Boubaker, H.; Boudyach, E.I.; Ben Aoumar, A.A. Control of Gray Mold Disease of Tomato by Postharvest Application of Organic Acids and Salts. Plant Pathol. J. 2017, 16, 62-72.

10. Palou, L. Postharvest Treatments with GRAS Salts to Control Fresh Fruit Decay. Horticulturae 2018, 4, 46. [CrossRef]

11. Chan, D.C. Mitochondria: Dynamic organelles in disease, aging, and development. Cell 2006, 125, 1241-1252. [CrossRef]

12. Osiewacz, H.D. Aging in fungi: Role of mitochondria in Podospora anserina. Mech. Ageing Dev. 2002, 123, 755-764. [CrossRef]

13. Kowaltowski, A.J.; de Souza-Pinto, N.C.; Castilho, R.F.; Vercesi, A.E. Mitochondria and reactive oxygen species. Free Radical Bio. Med. 2009, 47, 333-343. [CrossRef] [PubMed]

14. Simionato, A.S.; Navarro, M.O.P.; de Jesus, M.L.A.; Barazetti, A.R.; da Silva, C.S.; Simões, G.C.; Balbi-Peña, M.I.; de Mello, J.C.P.; Panagio, L.A.; de Almeida, R.S.C.; et al. The Effect of Phenazine-1-Carboxylic Acid on Mycelial Growth of Botrytis cinerea Produced by Pseudomonas aeruginosa LV Strain. Front Microbiol. 2017, 8 , 1102. [CrossRef] [PubMed]

15. Bocate, K.P.; Reis, G.F.; de Souza, P.C.; Oliveira Junior, A.G.; Durán, N.; Nakazato, G.; Furlaneto, M.C.; de Almeida, R.S.; Panagio, L.A. Antifungal activity of silver nanoparticles and simvastatin against toxigenic species of Aspergillus. Int. J. Food Microbiol. 2019, 291, 79-86. [CrossRef] [PubMed]

16. Fallanaj, F.; Ippolito, A.; Ligorio, A.; Garganese, F.; Zavanella, C.; Sanzani, S.M. Electrolyzed sodium bicarbonate inhibits Penicillium digitatum and induces defence responses against green mould in citrus fruit. Postharv. Biol. Technol. 2016, 115, 18-29. [CrossRef]

17. Li, B.; Lai, T.; Qin, G.; Tian, S. Ambient $\mathrm{pH}$ stress inhibits spore germination of Penicillium expansum by impairing protein synthesis and folding: A proteomic-based study. J. Proteome Res. 2010, 9, 298-307. [CrossRef] [PubMed]

18. Guo, Y.; Liu, L.; Zhao, J.; Bi, Y. Use of silicon oxide and sodium silicate for con-trolling Trichothecium roseum postharvest rot in Chinese cantaloupe (Cucumis melo L.). Int. J. Food Sci. Technol. 2007, 42, 1012-1018. [CrossRef]

19. Bi, Y.; Tian, S.P.; Guo, Y.R.; Ge, Y.H.; Qin, G.Z. Sodium silicate reduces posthar-vest decay on Hami melons: Induced resistance and fungistatic effects. Plant Dis. 2006, 90, 279-283. [CrossRef]

20. Hervieux, V.; Yaganza, E.S.; Arul, J.; Tweddell, R.J. Effect of organic and inorganicsalts on the development of Helminthosporium solani, the causal agent of potato silver scurf. Plant Dis. 2002, 86, 1014-1018. [CrossRef]

21. Palou, L.; Usall, J.; Muñoz, J.A.; Smilanick, J.L.; Vinas, I. Hot water, sodium carbonate, and sodium bicarbonate for the control of postharvest green and blue molds of Clementine mandarins. Postharv. Biol. Technol. 2002, 24, 93-96. [CrossRef]

22. Smilanick, J.L.; Mansour, M.F.; Margosan, D.A.; Mlikota Gabler, F.; Goodwine, W.R. Influence of pH and $\mathrm{NaHCO}_{3}$ on effectiveness of imazalil to inhibit germination of Penicillium digitatum and to control postharvest green mold on citrus fruit. Plant Dis. 2005, 89, 640-648. [CrossRef] [PubMed]

23. Ippolito, A.; Schena, L.; Pentimone, I.; Nigro, F. Control of postharvest rots of sweet cherries by preand postharvest applications of Aureobasidium pullulans in combination with calcium chloride or sodium bicarbonate. Postharv. Biol. Technol. 2005, 363, 245-252. [CrossRef]

24. Gregori, R.; Borsetti, F.; Neri, F.; Mari, M.; Bertolini, P. Effects of potassium sorbate on postharvest brown rot of stone fruit. J. Food Prot. 2008, 71, 1626-1631. [CrossRef] [PubMed] 
25. Li, Y.C.; Bi, Y.; Ge, Y.H.; Sun, X.J.; Wang, Y. Antifungal activity of sodium silicate on Fusarium sulphureum and its effect on dry rot of potato tubers. J. Food Sci. 2009, 74, 213-218. [CrossRef] [PubMed]

26. Youssef, K.; Mustafa, Z.M.M.; Al-Essawy, A. Efficacy of alkaline and acidic electrolysed water generated by some salt solutions against gray mold of table grape: Pre and postharvest applications. J. Phytopathol. Pest Manag. 2018, 5, 1-21.

27. Youssef, K.; Ligorio, A.; Sanzani, S.M.; Nigro, F.; Ippolito, A. Evaluation of direct activity and induction of resistance of some common food additives against green mold of citrus fruit. J. Plant Pathol. 2010, 92, 67.

28. Youssef, K.; Ligorio, A.; Nigro, F.; Ippolito, A. Activity of salts incorporated in wax in controlling postharvest diseases of citrus fruit. Postharv. Biol. Technol. 2012, 65, 39-43. [CrossRef]

29. Youssef, K.; Ligorio, A.; Sanzani, S.M.; Nigro, F.; Ippolito, A. Control of storage diseases of citrus by pre- and postharvest application of salts. Postharv. Biol. Technol. 2012, 72, 57-63. [CrossRef]

30. Hussien, A.; Ahmed, Y.; Al-Essawy, A.; Youssef, K. Evaluation of different salt-amended electrolysed water to control postharvest moulds of citrus. Tropical Plant Pathol. 2018, 43, 10-20. [CrossRef]

31. Liu, J.; Zong, Y.; Qin, G.; Li, B.; Tian, S. Plasma membrane damage contributes to antifungal activity of silicon against Penicillium digitatum. Curr. Microbiol. 2010, 61, 274-279. [CrossRef]

32. Huang, Y.J.; Chang, P.F.L.; Huang, J.W.; Lin, J.J.; Chung, W.H. Effect of Nanoscale Silicate Platelets on Azoxystrobin-resistant Isolates of Botrytis cinerea from Strawberry In Vitro and In Vivo. J. Plant Pathol. Microbiol. 2016, 7, 194-199. [CrossRef]

33. Kim, S.W.; Kim, K.S.; Lamsal, K.; Kim, Y.J.; Kim, S.B.; Jung, M.; Sim, S.J.; Kim, H.S.; Chang, S.J.; Kim, J.K.; et al. An in vitro study of the antifungal effect of silver nanoparticles on oak wilt pathogen Raffaelea sp. J. Microbiol. Biotechnol. 2009, 19, 760-764. [PubMed]

34. Lamsal, K.; Kim, S.W.; Jung, J.H.; Kim, Y.S.; Kim, K.S.; Lee, Y.S. Application of silver nanoparticles for the control of colletotrichum species in vitro and pepper anthracnose disease in field. Mycobiol. 2011, 39, 194-199. [CrossRef] [PubMed]

35. He, L.; Liu, Y.; Mustapha, A.; Lin, M. Antifungal activity of zinc oxide nanoparticles against Botrytis cinerea and Penicillium expansum. Microbiol. Res. 2011, 166, 207-215. [CrossRef] [PubMed]

36. Miguel, T.A.; Bordini, J.G.; Saito, G.H.; Andrade, C.G.; Ono, M.A.; Hirooka, E.Y.; Vizoni, E.; Ono, E.Y. Effect of fungicide on Fusarium verticillioides mycelial morphology and fumonisin B(1) production. Braz. J. Microbiol. 2015, 46, 293-299. [CrossRef] [PubMed]

37. Hashim, A.F.; Youssef, K.; Abd-Elsalam, K.A. Ecofriendly nanomaterials for controlling gray mold of table grapes and maintaining postharvest quality. Eur. J. Plant Pathol. 2019, 154, 377-388. [CrossRef]

38. Shi, X.Q.; Li, B.Q.; Qin, G.Z.; Tian, S.P. Antifungal activity of borate against Colletotrichum gloeosporioides and its possible mechanism. Plant Dis. 2011, 95, 63-69. [CrossRef] [PubMed]

39. Pezet, R.; Pont, V. Ultrastructural observations of pterostilbene fungitoxicity in dormant conidia of Botrytis cinerea Pers. J. Phytopathol. 1990, 129, 29-30. [CrossRef]

40. Avis, T.J.; Rioux, D.; Simard, M.; Michaud, M.; Tweddell, R.J. Ultrastructural alterations in Fusarium sambucinum and Heterobasidion annosum treated with aluminum chloride and sodium metabisulfite. Phytopathol. 2009, 99, 167-175. [CrossRef] [PubMed]

41. Rasooli, I.; Rezaei, M.B.; Allameh, A. Growth inhibition and morphological alterations of Aspergillus niger by essential oils from Thymus eriocalyx and Thymus x-porlock. Food Control 2006, 17, 359-364. [CrossRef]

42. Liu, X.; Wang, L.P.; Li, Y.C.; Li, H.Y.; Yu, T.; Zheng, X.D. Antifungal activity of thyme oil against Geotrichum citri-aurantii in vitro and in vivo. J. Appl. Microbiol. 2009, 107, 1450-1456. [CrossRef] [PubMed]

43. Jeong, J.; Kim, C.; Yoon, J. The effect of electrode material on the generation of oxidants and microbial inactivation in the electrochemical disinfection processes. Water Res. 2009, 43, 895-901. [CrossRef] [PubMed]

44. Singh, L.P.; Gill, S.S.; Tuteja, N. Unraveling the role of fungal symbionts in plant abiotic stress tolerance. Plant Sign. Behav. 2011, 6, 175-191. [CrossRef] [PubMed]

45. Qin, G.; Liu, J.; Cao, B.; Li, B.; Tian, S. Hydrogen peroxide acts on sensitive mitochondrial proteins to induce death of a fungal pathogen revealed by proteomic analysis. PLoS ONE 2011, 6, e21945. [CrossRef] [PubMed]

46. Liu, J.; Sui, Y.; Wisniewski, M.; Droby, S.; Tian, S.; Norelli, J.; Hershkovitz, V. Effect of heat treatment on inhibition of Monilinia fructicola and induction of disease resistance in peach fruit. Postharv. Biol. Technol. 2012, 65, 61-68. [CrossRef]

47. Shi, X.; Li, B.; Qin, G.; Tian, S. Mechanism of antifungal action of borate against Colletotrichum gloeosporioides related to mitochondrial degradation in spores. Postharv. Biol. Technol. 2012, 67, 138-143. [CrossRef] 
48. Li, Y.; Shao, X.; Xu, J.; Wei, Y.; Xu, F.; Wang, H. Tea tree oil exhibits antifungal activity against Botrytis cinerea by affecting mitochondria. Food Chem. 2017, 234, 62-67. [CrossRef] [PubMed]

49. Ji, D.; Chen, T.; Ma, D.; Liu, J.; Xu, Y.; Tian, S. Inhibitory effects of methyl thujate on mycelial growth of Botrytis cinerea and possible mechanisms. Postharv. Biol. Technol. 2018, 142, 46-54. [CrossRef]

50. Acton, B.M.; Jurisicova, A.; Jurisica, I.; Casper, R.F. Alterations in mitochondrial membrane potential during pre-implantation stages of mouse and human embryo development. Mol. Hum. Repr. 2004, 10, $23-32$. [CrossRef] [PubMed]

51. Helmerhorst, E.J.; Troxler, R.F.; Oppenheim, F.G. The human salivary peptide histatin 5 exerts its antifungal activity through the formation of reactive oxygen species. Proc. Natl. Acad. Sci. USA 2001, 98, 14637-14642. [CrossRef] [PubMed]

(C) 2019 by the authors. Licensee MDPI, Basel, Switzerland. This article is an open access article distributed under the terms and conditions of the Creative Commons Attribution (CC BY) license (http://creativecommons.org/licenses/by/4.0/). 